\begin{tabular}{rr} 
çağdaş & Yaratıcı Drama Dergisi 2018, 13(2), 173-188 \\
drama & www.yader.org \\
\hline
\end{tabular}

\title{
Leonardo Da Vinci'nin “Son Akşam Yemeği” Adlı Eserinin Yaratıcı Drama Yöntemiyle Çözümlenmesinde Öğrenci Görüşlerinin Belirlenmesi
}

\begin{tabular}{|c|c|}
\hline \multicolumn{2}{|r|}{$\begin{array}{l}\text { Abdulgafar Terzi }{ }^{1} \\
\text { Nami Eren Beştepe }\end{array}$} \\
\hline Makale Bilgisi & $\ddot{\mathbf{O ̈ z}}$ \\
\hline DOI: $10.21612 /$ yader.2018.013 & $\begin{array}{l}\text { Drama ve sanat eğitimi ilişkisi son yıllarda artmaya başlamıştır. Dramanın sanat } \\
\text { alanını ve sanat eğitimini olumlu etkileyebileceği düşünülmektedir. Özellikle son }\end{array}$ \\
\hline Makale Geçmişi & yıllarda okullarda dramanın sanat eğitiminde yöntem olarak kullanılmast, sanatı \\
\hline Geliş tarihi & $\begin{array}{l}\text { dolayısıly da sanat eğitimini ögrenciler tarafindan daha eğitici ve ögretici hale } \\
\text { getirmiștir. Bu çalıșmada 15. yüzyılın sonlarında (1495-1498) Leonardo Da Vinci'nin }\end{array}$ \\
\hline 05.07 .2018 & $\begin{array}{l}\text { "Son Akşam Yemeği " adlı tablosu temel alınmış olup, öğrencilerin yaratıcı drama } \\
\text { yöntemiyle bir eseri çözümleme ve alımlamalarına iliş̧kin görüşleri belirlenmeye } \\
\text { çalışılmıştır. Bu noktadan hareketle çalışmanın genel amacı, öğrencilerin Leonardo } \\
\text { Da Vinci'nin "Son Akşam Yemeği" adlı eserini yaratıcı drama yöntemiyle }\end{array}$ \\
\hline Anahtar Sözcükler & çözümlemelerini ve alımlamalarını sağlamaktır. Çalışma grubu, MEB'e bağlı \\
\hline & $\begin{array}{l}\text { bir devlet okulunun 6. ve 7. sinıf ögrencilerinden } 11 \text { ve } 13 \text { yaşs aralığında, daha } \\
\text { önce drama yaşantısı olmayan } 14 \mathrm{klz}, 2 \text { erkek ögrenci olmak üzere toplam } 16\end{array}$ \\
\hline Sanat & öğrenciden oluşmuştur. Araştırmada nitel araştırma yönteminden yararlanılmış, \\
\hline Sanat eseri & $\begin{array}{l}\text { odak grup görüşmesiyle veriler toplanmış ve elde edilen verilerin betimsel analizi } \\
\text { yapılmıştır. Drama yöntemiyle işlenen sürecin sonucunda ögrencilerin eleştirel }\end{array}$ \\
\hline Sanat eğitimi & anlamda daha fazla pratik yapmalarına olanak sağlandığl, ögrencilerin bir resme \\
\hline Leonardo Da Vinci & $\begin{array}{l}\text { nasıl bakılacă̆ını, resmin biçim içerik özelliklerini ve sanatsal düzenleme ögelerini } \\
\text { kavradıkları görülmüşür. }\end{array}$ \\
\hline \multicolumn{2}{|c|}{$\begin{array}{l}\text { Determining of Students' Views Regarding the Analysis of } \\
\text { "Last Supper" by Leonardo Da Vinci Through Creative Drama }\end{array}$} \\
\hline Article Info & Abstract \\
\hline DOI: $10.21612 /$ yader.2018.013 & $\begin{array}{l}\text { The relationship between drama and art education has begun to increase in recent } \\
\text { years. It is conjectured that the drama might positively influence the art field and }\end{array}$ \\
\hline Article History & $\begin{array}{l}\text { art education. Especially in recent years, the use of drama as a method in art } \\
\text { education in schools has made art education more educational for students. This }\end{array}$ \\
\hline 18.06.2018 & study was based on the "Last Supper" by Leonardo Da Vinci at the end of the 15th \\
\hline 05.07 .2018 & $\begin{array}{l}\text { century (1495-1498) and attempted to identify the views of the students resting on } \\
\text { the analysis and reception of the work through creative drama. The general aim } \\
\text { of this study is to help students analyze and receive the work "Last Supper" by } \\
\text { Leonardo Da Vinci's through the creative drama. The study group consisted of } 16\end{array}$ \\
\hline Keywords & $\begin{array}{l}\text { students, } 14 \text { females and } 2 \text { males, who neverhad drama experience previously, aged } \\
\text { between } 11 \text { and } 13 \text { years of 6th and 7th grade students of a state school affiliated }\end{array}$ \\
\hline Drama & to Turkish Ministry of Education. Qualitative research method was used in the \\
\hline Art & $\begin{array}{l}\text { research, and data were gathered via focus group interview, and descriptive analysis } \\
\text { of the obtained data was done. As a result of the process through drama method, it }\end{array}$ \\
\hline Artistic work & was found that students were allowed to fulfill more practice through critical lens, \\
\hline Art education & $\begin{array}{l}\text { learned how to look at and interpret a painting, and comprehended the features of } \\
\text { form and content and artistic regulation elements. }\end{array}$ \\
\hline Leonardo Da Vinci & \\
\hline
\end{tabular}

Öğretmen, MEB, E-posta: terzigaffar@gmail.com

2 Dr. Öğretim Üyesi, Hatay Mustafa Kemal Üniversitesi, E-posta: nbestepe@gmail.com. 


\section{Giriş}

İnsanoğlu geçmişten günümüze kadar sanatla iç içe olmuştur. Bu süreçte sanat, yaşamın vazgeçilmez bir unsuru ve kişilerin eylemlerinin de önemli bir parçası durumuna gelmiştir. Yaşamın sanatla birleştiği bu tür durumlarda insan hep bir arayış içerisine girmiş, sanatın gücünü daima kullanmaya devam etmiştir. Botton (2007, s.116), "Mağara duvarlarına resim yapanlar ve bu resimlerle karşılaşanlar yok olup gittikten sonra bile yapılan bu resimler hâlâ bizlere çok şeyler anlatabiliyor. Öyle ki karşılaştığımız güzel bir nesne her yönüyle bizi etkisi altına alabiliyor ve onun hakkında değer yargılarına varabiliyoruz". Botton sanatın uzun süreli etkisinden söz ederken; Read (2014, s.32) sanatın güçlü etkisinden söz ederek şu ifadeleri dile getirmiştir; "Bence sanatın öyle etki yapıcı bir özelliği vardır ki... Bu özellik sadece parçalar arasında bir bağlantı ve düzen görme değildir; her parça, bütünü gibi bir çeşit duygululukla dolar. Bizim saf güzellik tanımımıza göre bu duygu hayatta yaşanmış heyecanların hatırlanmasından veya sezilmesinden doğmaz; buna rağmen bunun bazı derin, belirsiz ve çok genelleşmiş hatıralardan kuvvet aldığını da bazen düşünürüm”. Botton ve Read sanatın güçlü etkisinin ancak yaşamla sanatın birlikte harmanladığında daha derin anlamlarnın olduğunu dile getirmişlerdir. Sanatın yaşamımıza kattığı anlam arayışları günümüzde her yönden daha etkin kullanılmaya başlamıştır. Sanat aracılığıyla yapılan tüm bu yararlar bize sanatın estetiksel anlamda bir değerlendirmeye tabi tutulacağını da göstermiştir. Sanat, biçemini göz önünde tutup zevk amaçlı eserler oluştururken sanatın insana özgü özelikler de taşıdığını görürüz. Taşıdığı bu özellikler göz önünde bulundurulduğunda sanat kavramı, sanat eseri aracılığıyla daha da anlamlı olmaya başlamıştır. Fakat sanat eğitiminin günümüz eğitim sisteminde ne kadar yer aldığı, sanattan ve sanat eserlerinden öğrencilerin ne derece beslendiği hep tartışma konusu olmuştur. Kant (Akt.Tanilli, 1999, s.447) eğitimdeki soruna şu açıdan bakar: "İnsanoğlunun güçleri arasında sayabileceğimiz iki buluşu vardır ki, bunlar da insanları yönetme sanatı ile onları eğitme sanatıdır". Kant'ın güç olarak gördüğüne sanat eğitimi açısından bakan Özer (2000, s.35) görüşlerini “Sanat görüşü, anlayışı ve yorumlayışı bakımından hızlı ve yoğun bir eğitime ihtiyaç olan ülkemizde, sanatı öğreten, uygulatan ve de yayan kurumların her türlü geçerlilikten yoksun klişeleri toplumun zihninden silip atması kaçınılmaz bir görevdir.” şeklinde ifade etmiştir.

Yolcu (2009, s.93) “Sanat eğitimi; kişiye estetik yargı yapabilme konusunda yardımcı olmayı amaçlarken, yeni biçimleri hissedip, heyecanlarını doğru biçimlerde yönlendirmeyi öğretir. Demek ki sanat eğitimi, sanatçı yetiştirmeye değil, yetiştirmek durumunda olduğu her kişiyi yaratıcılığa yöneltip, onun bilişsel, duyuşsal ve duygusal eğitim ihtiyaçlarını karşılamaya yöneliktir” şeklinde ifade eder.

Aykut ise (2011, s.94) düşüncelerini "Sanat eğitiminin yalnız insana özgü bir gereksinim olduğu varsayımından hareket edersek, bireyin tüm ruhsal ve bedensel eğitimi, bütünlüğü içinde estetik duyguları geliştirilmesi, yetenek ve yaratıcılık gücünün olgunlaştırılması çabası sanat eğitiminin anlamına açık bir görüntü kazandırır.” şeklinde ifade etmiştir. Aykut sanat eğitiminin yalnız insana özgü gereksinimlerinden bahsederken, San (1979, s.3) "Şu da iyice belirtilmelidir ki sanat eğitiminin amacı sanat için eğitim, yani belli uğraşısı olan bir sanatçı yetiştirmek değildir. Amaç sanatla eğitimdir; gerek sanat uğraşında bulunan kişide, gerek sanat eseri ile karşılaşıp onu değerlendirende harekete geçen tüm zihinsel yeti ve süreçleri, duyu, duyum, algılama, imgeleme, düşünme, anma, çağrışım gibi güçleri eğitmektir. Sanatı algılamaya hazır ve sanatı seven, hem eskinin, hem çağının sanat görüngülerini (phenomenon) algılayıp değerlendirebilecek kişiler yetiştirmektir”. 
Beştepe (2006, s.8) ise bu konudaki görüşlerini “Günümüzde sanatsal yaratım sonucunda sanat yapıtlarının ortaya konması kadar bu yapıtların açıklanmasına, anlaşılmasının sağlanmasına ve değerlendirilmesine de gereksinim duyulduğundan söz edilebilir. Bir yapıtın açıklanmasının ve değerlendirilmesinin, o yapıtın tanıtılmasına ve anlaşılmasına etkisi olabileceği gibi sanat kuramlarının, estetik kuramlarının ve sonuçta sanatın gelişimine de katkı sağlayacağı düşünülebilir.” şeklinde ifade etmiştir. Dolayısıyla okullardaki görsel sanatlar dersinde ve diğer derslerde bir sanat eseriyle karşılaşan öğrencilere sadece soruların sorulup cevapların alındığı bir öğretim yöntemi uygulanmamalıdır. Bu tür öğretim yöntemlerinin kullanılması öğrenciyi sınıf içerisinde pasifleştirip, sanat eserinden elde edilen bilgilerin de yaşamla ilişkisinin kurulmasını engellemiş olur. Öğrencilerin sınıf içerisinde pasifliğini daha da artıran bu tür yöntemler, sanat eserlerinden edinilen bilgilerin amacına uygun kullanılmamasına da neden olur. Okullarımızda geleneksel öğretim yöntemleriyle öğrencilere verilen sanat eleştirisi öğretimi, sanat eserleri hakkında kuru bilgilerin ezberlenmesinden öteye geçmemektedir. İlter (2014, s.564) bu düşünceye uygun olarak görüşlerini şöyle ifade eder; “Geleneksel öğretim yöntemleri ve düz anlatım yönteminin kullanıldığı bir derste öğrenci etkileşimi olmamakta ve anlatım tek yönlü iletişime dayalı öğretmen merkezli yöntem olarak ortaya çıkmaktadır. Nitekim doğrudan anlatım yönteminde iletişim ve etkileşimden çok iletim yani doğrudan aktarım söz konusu olmaktadır. Çünkü bu yöntem, öğretmenin sunuş yoluyla öğrencilerine doğrudan bilgi ve beceriler kazandırdığı, dolayısıyla öğrencilerin öğrenme sürecinin merkezinde olmadığı bir yöntemdir. Öğrenci, verilen bilgileri pasif olarak dinlediğinden herhangi bir etkileşimde bulunamaz". Tanımdan da anlaşılacağı üzere geleneksel yöntemlerle işlenen derslerde öğrenci yalnızca bilgileri alan yani pasif dinleyici durumunda kalmaktadır. Fakat öğrenci doğası gereği harekete ve oyuna düşkündür. Bu açıdan bakıldığında sanat eleştirisi öğretiminde hareketin ve oyununun ön planda olduğu bir öğretim yöntemine ihtiyaç duyulmaktadır. Dolayısıyla da sanat eserlerini çözümleme ve alımlama noktasında etkili ve doğru yöntemlerin kullanılması gerekli bir unsur olarak karşımıza çıkar. Bu açıdan baktığımızda yaratıcı drama yöntemi, sanat eserlerini anlama ve anlamlandırma sürecinde öğrencilerin sanat eserleri üzerinden düşünmeleri, sorgulama yapmaları ve yaratıcı bir süreci yaşamaları açısından önemlidir. Yaratıcı drama yöntemiyle öğrencinin düşünme ve sorgulamayla başlayan yaratıcı serüveni yine bu yöntemde kullanılan tekniklerle öğrencide sanat eğitiminin kazanımlarını daha da kalıcı hale getirir. Ayrıca sanat ve yaratıcı drama gibi disiplinlerin bir araya gelmesi sanat eğitimi alanına farklı bir yaklaşım getirmesi bakımından da önemli görülmüştür.

Sağlam (2006, s.57)’a göre ‘Öğrencinin kendini en çok bulduğu ve enerjisini kullandığı ortam oyun ortamıdır. $\mathrm{Bu}$ ortamda gerçekleşen her şey öğrencilerin yapacağı çalışmayı benimsemesini, kendi isteğiyle yapmasını sağlar. Dolayısıyla sanat eğitimi ancak kişinin özgürce oynayabileceği oyun ortamında olabilir." Oyun oynama ve canlandırmaların etkin rol oynadığı yaratıcı dramayı bilgi edinmede yararlı bir araç olarak gören Sağlam, Bolton'un sözlerini "Drama dersi hem eğitimin hem de sanatın isteklerini karşılayacak biçimde yapılandırıldığında öğrenme/öğretme deneyimi daha etkin olacaktır." şekilde aktarır. Sanat ve sanat eserinden yola çıkılarak gerçekleştirilen tüm süreçler de bize drama ve sanatın ne kadar iç içe olduğunu gösterir.

İlhan (2007, s.140) "Yaratıcılığın gelişmesinde bilindiği gibi sanat eğitiminin önemli bir yeri vardır. Yaratıcı drama eğitimi de aynı zamanda bir sanat eğitimidir. Yaratıcı drama tüm sanat alanları ile iç içedir. Yaratıcı drama ile ilgilenen biri sanat olaylarını, sanat kuramlarını, sanat akımlarını, sanat eleştirilerini takip etmeli; tiyatro, bale, konser, sergi vb. etkinliklere katılmalı, bunları izlemeli en azından bunlardan haberdar olmalıdır". Yukarıdaki açıklamalar yaratıcı dramanın tüm duyu 
organlarımızı kullanarak diğer sanatlarla olan bağı güçlendirdiğini göstemektedir. Vural \& Somers (2011, s.81), "Eğitimde yaratıcı drama yolu ile pek çok içerik birimini öğretmeye yönelik öğrenmeöğretme çerçevesi hazırlanırken, resim, müzik, fotoğraf, heykel gibi sanat alanlarına ilişkin ürünler de birer araç olarak kullanılmaktadır." şeklinde ifade eder. Yaratıcı dramanın görmeyi sağlayan en önemli araç olduğunu söyleyen Adıgüzel ise (2002, s.336) düşüncelerini "Yaratıcı drama geniş anlamda bir görme eğitimi, görmeyi öğreten bir süreçtir. Görmenin buradaki anlamı düşünmeyle bütünleşmektedir. Göz duyarlılığ gelişmiş, görmeyi öğrenmiş, gördüklerini düşünmeyle birleştirmiş olan, müzik dinlerken, öykü okurken, şiir dinlerken de o sanat yapıtının iletisini "görerek" onu daha kolay anlayacaktır." şeklinde ifade etmiştir. Genel anlamda yaratıcı dramanın kendi iç dinamiklerinin sanatın iç dinamikleriyle ne kadar örtüştüğünü, başta sanat eleştirisi olmak üzere ve bunu takip eden tüm sanat dallarını da içine alan bir disiplin özelliği taşıdığını görmekteyiz.

\section{Araştırmanın Amacı}

Araştırmanın genel amacı, araştırmaya katılan öğrencilerin Leonardo Da Vinci'nin “ Son Akşam Yemeği” adlı eserini yaratıcı drama yöntemiyle çözümleyerek alımlamalarını sağlamak ve bu konuya ilişkin görüşlerini belirlemektir. Bu genel amaçtan hareketle öğrencilerin;

1. Bir sanat eserine nasıl bakılacağına ilişkin görüşleri,

2. Sanat eseri incelemesinde yaratıcı dramanın yöntem olarak kullanılmasına ilişkin görüşleri,

3. Leonardo'nun Son Akşam Yemeği tablosundaki biçim ve içeriğin (kişiler, yemek, mekân) anlaşılıp, anlaşılmadığına ilişkin görüşleri,

4. Bir sanat eserinde sanatsal düzenleme ögelerinin ( çizgi, şekil, 1şık- gölge, doku, renk, biçim, değer, ton, mekân v.b ) anlaşılıp, anlaşılmadığına ilişkin görüşleri,

5. Yaratıcı dramaya ilişkin görüşleri, belirlenmeye çalışılmıştır.

\section{Yöntem}

\section{Araştırmanın Modeli}

Öğrencilerin, Leonardo Da Vinci'nin “Son Akşam Yemeği” adlı eserinin yaratıcı drama yöntemiyle çözümlemeleri ve alımlamaları amaçlanan araştırma, nitel araştırma yöntemine dayalı bir araştırmadır. Nitel araştırma; gözlem, görüşme ve doküman analizi gibi nitel veri toplama yöntemlerinin kullanıldığı, algıların ve olayların doğal ortamda gerçekçi ve bütüncül bir biçimde ortaya konmasına yönelik nitel bir sürecin izlendiği araştırmadır (Yıldırım ve Şimşek, s.2006).

Leonardo Da Vinci’nin “Son Akşam Yemeği” adlı eserinin seçilmesinin nedeni, sanat tarihi açısından resim sanatının özelliklerini taşıması, resmin öğreticiliğinin ön planda tutulması, dramatik yapısının ve anlamının güçlü olmasıdır. Ayrıca eser içinde somut nesnelerin bulunması, eserin güçlü bir hikâyesinin olması, tarihsel ve estetik bir değer taşıması ve tablo içerisinde üçlü figürlerin birbirleriyle dramatik ilişkisi de bu resmin seçilmesinde önemli noktalardır. 


\section{Çalışma Grubu}

Çalışma grubu, MEB'e bağlı bir devlet okulunun 6. ve 7. sınıf öğrencilerinden 11 ve 13 yaş aralığında, daha önce yaratıcı drama yaşantısı olmayan 14 kız, 2 erkek öğrenci olmak üzere toplam 16 öğrenciden oluşmuştur.

\section{Verilerin Toplanması ve Analizi}

Araştırma kapsamında ulaşılan veriler odak grup görüşmesi aracılığıyla elde edilmiştir. Odak grup görüşmesi "1lımlı ve tehditkar olmayan bir ortamda önceden belirlenmiş bir konu hakkında algıları elde etmek amacıyla dikkatle planlanmış bir tartışmalar serisi”" olarak tanımlanabilir (Yıldırım ve Şimşek, 2006). Araştırmanın amacı doğrultusunda beş tane açık uçlu sorudan oluşan bir görüşme formu hazırlanmıştır. Bu formun geliştirilmesinde alan yazında yer alan örnek formlar dikkate alınarak maddeler yazılmış ve bu maddeler 4 uzman tarafından incelenmiştir. Uzmanların önerileri dikkate alınarak görüşme formunda gerekli düzenlemeler yapılmış ve forma son hali verilmiştir. Formda yer alan beş soru şöyledir: 1. Bu çalışmadan önce bir sanat eserine nasıl bakardınız, şimdi nasıl bakıyorsunuz? 2. Sanat eseri incelenmesinde yaratıcı dramanın yöntem olarak kullanılmasına ilişkin neler düşünüyorsunuz? 3. Leonardo'nun Son Akşam Yemeği tablosunun biçim ve içerik özelliklerine (kişiler, yemek, mekân) ilişkin neler söyleyebilirsiniz? 4. Leonardo'nun Son Akşam Yemeği tablosunda sanatsal düzenleme ögelerini ( çizgi, şekil, 1şık- gölge, doku, renk, biçim, değer, ton, mekân vb.) görebildiniz mi? 5. Yaratıcı drama çalışmasını nasıl buldunuz, yaratıcı dramayla ilgili görüşleriniz nelerdir? Bu beş soru, son oturumun bitiminden sonra gruba yöneltilmiş ve elde edilen veriler bilgisayar ortamına aktarılarak derlenmiş, araştırma soruları ile ilişkilendirilerek analiz edilmiş ve kayıt altına alınmıştır.

Araştırmada elde edilen verilerin çözümlenmesinde betimsel analiz tekniği kullanılmıştır. Betimsel analizde elde edilen veriler daha önceden belirlenen temalara göre özetlenir ve yorumlanır (Yıldırım ve Şimşek, 2006). Odak grup görüşmesiyle elde edilen öğrenci görüşleri "Sanat Eseri, Yaratıcı Drama Aracılığıyla Sanat Eseri İnceleme, Sanat Eserinde Biçim ve İçerik, Yaratıcı Drama, Sanatsal Düzenleme Ögeleri” alt başlıkları altında yorumlanmıştır.

Araştırmada elde edilen bulgularda, araştırmanın güvenirliğini desteklemek amacıyla öğrencilerin yanıtlarından aynen alıntılar yapılmıştır. Doğrudan alıntılarda öğrencilerin sözleri (Ö, numara) şeklinde gösterilmiştir. Ayrıca, yine araştırmanın güvenirliğini desteklemek amacıyla çocukların ve velilerinin izni ile atölye çalışmaları kamera ve fotoğraf çekimleriyle kayıt altına alınmıştır.

\section{Uygulama Süreci}

Leonardo Da Vinci'nin “Son Akşam Yemeği” adlı eserinin yaratıcı drama yöntemiyle çözümlenmesi ve alımlanması kapsamında altı konu belirlenerek yaratıcı drama yöntemi aşamaları (1sınma/hazırlık, canlandırma, değerlendirme) doğrultusunda yapılandırılmıştır. Uygulama atölyeleri toplam 24 saat olmak üzere 8 oturumda 4 Haziran 2013 - 19 Haziran 2013 tarihleri arasında gerçekleştirilmiştir. Oturum başlıkları; "Tanışma - İletişim”, "Sanatta Yaratma ve Yaratııılık", "Bir Sanat Eserindeki Tasarım İlkeleri ve Öğeleri”, "Son Akşam Yemeği Adlı Resimdeki İçerik”, "Son Akşam Yemeği Adlı Resimde Mekan ve Kişiler”, "Son Akşam Yemeği Adlı Resimdeki Giysiler ve Yemek”, Leonardo Da Vinci’nin Hayatı ve Sanat Anlayışı” ve “Genel Değerlendirmedir”. 


\section{Bulgular ve Yorum}

Araştırma kapsamında ulaşılan bulgular, araştırma soruları ile ilişkili olarak; Sanat Eseri, Yaratıcı Drama Aracılığıyla Sanat Eseri İnceleme, Sanat Eserinde Biçim ve İçerik, Yaratıcı Drama ve Sanatsal Düzenleme Öğeleri olmak üzere beş alt başlıkta sunulmuştur.

\section{Sanat Eseri}

Sanat eseri alt başlığında, öğrencilerin bu çalışmadan önce ve sonra bir sanat eserine nasıl baktıkları belirlenmeye çalışılmıştır. Öğrencilerin sanat eserine bakmakla ilgili görüşleri Tablo 1'de gösterilmiştir.

Tablo 1. Sanat Eserine Bakmakla İlgili Öğrenci Görüşleri

\begin{tabular}{ll}
\hline Sanat Eseri & \multicolumn{1}{c}{ Öğrenci Görüşleri } \\
\hline & Ö.1. Resimlere öyle bakar geçerdim ya güzel ya da çirkin derdim ama şimdi artık sanatsal \\
& ögeleri kullanıp detaylarına bakabiliyorum. \\
& Ö.4. Önceden sadece resimlere bakıp iyi ve güzel deyip geçiştirirdim. Ama şimdi bir sürü \\
& yorum yapabiliyorum. Resimde yüz ifadelerine kıyafetlerine yemeklerine ve duruşlarına \\
& çok dikkat ediyorum. \\
& Ö.5. Yaratıcı drama etkinliklerine katılmadan önce bir sanat eserinin öğelerine dikkat \\
& etmezdim. Şimdi resmin öğelerini dikkate alarak resimdeki hareket ve mimikleri de dikkate \\
& alıorum. \\
& Ö.10. Normal bir şekilde güzelse güzel olmuş deyip geçerdim. Ama şimdi temel sanat \\
& öğelerine bakarak ve tablonun inceliklerine bakarak resmi daha iyi görebiliyorum. \\
& Ö.7. Önceden bir resme bakıp aa güzelmiş deyip geçerdim. Ama şimdi neler oluyor ve \\
& resimde neler var diye bakıyorum. \\
& Ö.11. İlk başta bakar geçerdim. Bunlar boşuna yapıorlar derdim ama şimdi çok güzel bir \\
& resim ve duruşları çok güzel diyorum. \\
& Ö.14. Herkesin merak ettikleri şeyler çok önemli olur ve onun neden çağlar boyunca merak \\
& edildiğini artık biliyorum.
\end{tabular}

Tablo 1'de öğrencilerin, sanat eserine bakmakla ilgili görüşleri incelendiğinde, bir sanat eseriyle ilk kez karşılaştıkları zaman hızlıca bakıp geçtikleri ve eser hakkında herhangi bir yargıda bulunmadıkları görülmüştür. Bunun yanında eserin kime ait olduğu, kim tarafından yapıldığı ve içeriğiyle ilgili bilgilerinin olmadığını belirtmişler ve eserlerin neden bu kadar değerli olduklarını anlamadıklarını ifade etmişlerdir. Öğrencilerin yaratıcı drama etkinliklerinden sonra süreç boyunca eser hakkındaki bilgileri çözümleyerek eseri daha iyi anladıkları, resimden ne anladıklarını yorumladıkları görülmüştür. Ayrıca eserlerdeki sanat elemanları ve tasarım ilkelerine de dikkat ederek resmi daha iyi anladıklarını söylemişlerdir.

\section{Yaratıcı Drama Aracılığıyla Sanat Eseri İnceleme}

Yaratıcı drama aracılığıyla sanat eseri inceleme alt başlığında, öğrencilerin Leonardo Da Vinci'nin Son Akşam Yemeği adlı eserinin yaratıcı drama etkinlikleriyle işlenmesi hakkındaki düşünceleri belirlenmeye çalışılmıştır. Öğrencilerin "Yaratıcı Drama Aracılığıyla Sanat Eseri İncelenmesine ilişkin görüşleri Tablo 2'de gösterilmiştir. 
Tablo 2. Leonardo Da Vinci’nin "Son Akşam Yemeği”" Adlı Eserinin Yaratıcı Dramayla İşlenmesi ile İlgili Öğrenci Görüşleri

\section{Sanat Eseriyle}

Darama

\section{Öğrenci Görüşleri}

Ö.2. Bence bu şekilde işlenmesini çok sevdim. Hem eğlendim hem öğrendim yani bu konuda çok olumlu pozitif düşünüyorum.

Ö.4. Canlandırmalar yaptık ve doğaçlamalar yaptık. Biz burada o tabloyu
canlandırdığımız için onların ne hissettiklerini ve neler yaşadığını anladım.
Ö.5. Yaratıcı drama da hem oyun oynayıp hem de eğleniyorum. Çünkü elimize bir kağıt verilip de okumamız istenseydi çok çabuk unuturduk ama şimdi eğlenerek daha iyi öğreniyoruz.
Ö.8. Son Akşam Yemeği tablosunda ayrıntılı bir şekilde öğreniyoruz. Oyunlarla canlandırmalarla daha iyi bir şekilde öğrendik.
Ö.10. Konuşarak bir şey anlaşılmıyor ama etkinlik yaparken eğlenerek öğreniyoruz. Bu da çok daha kalıcı oluyor.
Ö.12. Eğlenceliydi. Yaptığımız etkinlikler güzeldi ama ufak bazı sorunlar oldu. Ama arkadaşlar arasında olur böyle şeyler.

Ö.14. Konuyu eğlenerek öğrendik ve etkinlikler daha iyi anlamamıza yol açtı ve bu çok güzel bir şey.

Tablo 2'de öğrencilerin yaratıcı drama aracılığıyla sanat eseri incelemesine ilişkin görüşlerine bakıldığında, Leonardo Da Vinci'nin Son Akşam Yemeği adlı eserinin yaratıcı drama etkinlikleriyle işlenmesinin hem eğlendirici hem de öğretici olduğunu belirtikleri görülmüştür. Bunun yanı sıra tabloyla ilgili yapılan doğaçlama ve canlandırmaların resmi daha iyi anlamalarını sağladığı, canlandırmalarla resimdeki kişilerin ne hissettiklerini ve neler yaşadıklarını da kavradıklarını ifade etmişlerdir. Ayrıca öğrencilerin görüşlerine baktığımızda, dersin klasik bir şekilde işlenmesinin sıkıcı olacağı bunun yerine oyunun ve eğlencenin olduğu bir dersin ise onlara daha çok şey öğreteceği ve kalıcı olacağını belirtmiş oldukları görülmüştür.

\section{Sanat Eserinde Biçim ve İçerik}

Sanat eserinde biçim ve içerik alt başlığında, öğrencilerin Leonardo Da Vinci’nin “Son Akşam Yemeği” adlı resminin biçim ve içeriğini anlamalarıyla ilgili düşünceleri belirlenmeye çalışılmıştır. Öğrencilerin sanat eserinde biçim ve içerik ilişkisine ilişkin görüşleri Tablo 3 ’te gösterilmiştir. 
Tablo 3. Leonardo Da Vinci’nin "Son Akşam Yemeği”" Adlı Resminin biçim ve İçeriği ile İlgili Öğrenci Görüşleri

\begin{tabular}{|c|c|}
\hline $\begin{array}{l}\text { Sanat Eserinde } \\
\text { Biçim-İçerik }\end{array}$ & Öğrenci Görüsşleri \\
\hline 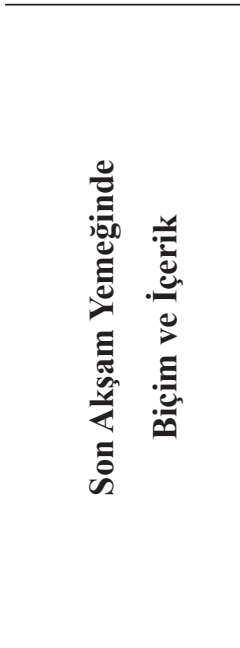 & $\begin{array}{l}\text { Ö.2. Bence bu şekilde işlenmesini çok sevdim. Hem eğlendim hem öğrendim yani bu } \\
\text { konuda çok olumlu pozitif düşünüyorum. } \\
\text { Ö.4. Evet düşünüyorum. Çünkü son akşam yemeği olduğu için yemekleri ve mekân } \\
\text { seçimleri çok önemli. } \\
\text { Ö.6. Evet düşünüyorum. Çünkü o konu ile ilgili oyun oynadık ve birçok şey yaparak } \\
\text { anladığımı düşünüyorum. } \\
\text { Ö.8. Evet düşünüyorum tablo içeriği, kişiler, yemek ve mekân, toplanma nedenleri bunun } \\
\text { yanında yüz ifadelerini daha iyi anladım. } \\
\text { Ö.10. Evet en çok temel sanat öğeleri ve estetik değerler yardımcı olduğunu düşünüyorum. } \\
\text { ÖK.12. Evet en çok da temel sanat öğelerini anladım. } \\
\text { Ö.14. Giysiler renkler ve döneme ve insana göre değişebilir. Örneğin kişinin kıyafetlerinin } \\
\text { rengine bakarak o kiş̧inin özelliklerini anlayabiliyor ve tahmin edebiliyorum. }\end{array}$ \\
\hline
\end{tabular}

Tablo 3'te öğrencilerin, sanat eserinde biçim ve içerik özelliklerine ilişkin görüşlerine bakıldığında Leonardo Da Vinci'nin “Son Akşam Yemeği” adlı resminin biçim ve içeriğini anladıklarını ifade ettikleri görülmüştür. Öğrenciler resimdeki biçim ve içeriğin sanat elemanları ve tasarım ilkeleriyle daha çok anlam kazandığını belirtmişlerdir. Ayrıca katılımcılar, resimdeki insanlar, mekân, yemek ve toplanma nedenleriyle ilgili düşüncelerini de söylemişlerdir.

\section{Yaratıcı Drama}

Bu alt başlıkta da öğrencilerin yaratıcı drama uygulamalarına yönelik görüşleri belirlenmeye çalışılmıştır. Öğrencilerin yaratıcı drama uygulamalarına ilişkin görüşleri Tablo 4’te gösterilmiştir.

Tablo 4. Leonardo Da Vinci'nin "Son Akşam Yemeği”" Adlı Tablosunun Yaratıcı Dramayla İslenmesi ile Ilgili Öğrenci Görüşleri

\begin{tabular}{ll}
\hline Yaratıı Drama & Öğrenci Görüşleri \\
\hline & $\begin{array}{l}\text { Ö.2. Ben bu süreçte çok eğlendim. Kıyafetler tasarladım bilgiler öğrendim yeni yeni } \\
\text { arkadaşlar edindim. O yüzden gerçekten çok mutluyum. }\end{array}$ \\
& Ö.3. Bu süreçte oyunlar oynadık ve eğlenerek öğrendik. Eğlenerek öğrenmek \\
& gerçekten de çok güzel bir yöntem. \\
& Ö.5. Evet gönüllü katıldım. Bu süreçte eğlendik oyunlar oynadık ve çok mutlu bir \\
& süreç geçirdik. \\
& Ö.7. Evet gönüllü katıldım. Canlandırmalar yaptık. Oyunlar oynadık, eğlendik ve \\
& resmi çözümledik. \\
& Ö.9. Kendi isteğimle katılım. Bazen güldük bazen eğlendik bazen üzüldük bazen de \\
& sıkıldığımız oldu ama çok güzeldi. \\
& Ö.11. Çok eğlendim ve çok sevdim. Resimde bir şey yapmışsam çok mutlu oluyorum. \\
& Ö.15. Herhangi bir drama çalışması yaratıcı olması için bir grubun olması gerekir. \\
& Yaratıcı drama eğlenerek öğrenmektir.
\end{tabular}


Tablo 4’te öğrencilerin, yaratıcı drama uygulamalarına ilişkin görüşlerine baktığımızda hepsi yaratıcı drama etkinliklerine gönüllü katıldıklarını ifade etmişlerdir. Süreç boyunca çok eğlendikleri, oyunlar oynadıkları, kıyafetler tasarladıkları ve yeni arkadaşlıklar edindiklerini belirtmişlerdir. Ayrıca öğrenciler eğlenerek öğrenmenin kendilerini çok mutlu ettiğini ve derste kullanılan bu yöntemin çok güzel bir yöntem olduğunu da söylemişlerdir. Öğrencilerden birkaçı ise oyunlarda bazen sıkıldıklarını fakat genel itibariyle güzel zaman geçirdiklerini ifade etmişlerdir.

\section{Sanatsal Düzenleme Ögeleri}

$\mathrm{Bu}$ alt başlık altında da öğrencilerin bir sanat eserinde sanatsal düzenleme ögelerini (çizgi, şekil, 1ş1k- gölge, doku, renk, biçim, değer, ton, mekân vb.) görüp göremedikleri belirlenmeye çalışılmıştır. Öğrencilerin sanatsal düzenleme ögelerine ilişkin görüşleri Tablo 5'te gösterilmiştir.

Tablo 5. Sanat Eserinde Sanatsal Düzenleme Ögelerini Görme ile İlgili Öğrenci Görüşleri

\begin{tabular}{ll}
\hline Sanat Ögeleri & Öğrenci Görüşleri \\
& $\begin{array}{l}\text { Ö.2. Evet artık görebiliyorum. Çünkü önce bunlara önem vermeyip bakıp geçerdim ama } \\
\text { artık böyle olmayacak. }\end{array}$ \\
& Ö.3. Evet kesinlikle görebiliyorum. Artık resimlere bakarken bu sanatsal düzenleme \\
& ögelerine dikkat ediyorum. \\
& Ö.5. Evet görebiliyorum çünkü bütün ögeleri yaparak ve yaşayarak öğrendik. \\
& Ö.8. Evet görebiliyorum. perspektifi çizgiyi, dokuyu, mekânı, tonu, gölgeyi, rengi, şekli \\
& Ö.9. Evet benim bildiğim kadarı̈yla her sanatta ve eserlerde bu ögeler vardır ve \\
& Ö.13. Biçim, perspektif, çizgi, gölge, doku, renk, zıtlık ve denge sanatsal düzenleme \\
& ögeleri olarak geçmektedir. \\
& Ö.15. Sanatsal düzenleme ögeleri öğrendim ve bunlar son akşam yemeği resmini \\
& anlamamızı sağladı
\end{tabular}

Tablo 5'te öğrencilerin sanatsal düzenleme ögelerine ilişkin görüşlerine baktığımızda bir sanat eserinde sanatsal düzenleme ögelerini (çizgi, şekil, 1ş1k- gölge, doku, renk, biçim, değer, ton, mekân v.b) görebildikleri belirlenmiştir. Daha önce bir sanat eseriyle karşılaştıklarında bu tür ögeleri göremediklerini (bilmedikleri), görmüş olsalar bile bu ögelerin onlar için bir anlam ifade etmediği dile getirilen görüşler arasındadır. Ayrıca bundan sonra bir sanat eseriyle karşılaştıklarında ilk dikkat edecekleri şeylerin bu ögeler olacağını da belirtmişlerdir. Öğrencilerin yaratıcı drama etkinlikleriyle sanat elemanları ve tasarım ilkelerini yaparak ve yaşayarak daha iyi çözümlediklerini ifade ettikleri de görülmüştür.

\section{Tartışma}

$\mathrm{Bu}$ araştırma öncelikle Leonardo Da Vinci’nin Son Akşam Yemeği adlı eserini temel almıştır. Araştırmada eserden yola çıkarak katılımcıların eseri çözümleme ve alımlamada yaratıcı drama yönteminin kullanılmasının öğrenci görüşlerine göre değerlendirilmesi istenmiştir. $\mathrm{Bu}$ amaç doğrultusunda çalışmanın bulgu ve yorumlarından çıkan sonuçlara bakıldığında Leonardo Da Vinci'nin Son Akşam Yemeği adlı eserinin yaratıcı drama yöntemiyle çözümlenmesi ve 
alımlanmasında öğrencilerin estetik deneyimleri, eseri çözümleme ve öğrenme süreçlerinde artışın olduğu tespit edilmiştir. Alan yazınına baktı̆̆ımızda yapılan araştırmalar, yaratıcı drama yönteminin öğrencilerin başarılarına anlamlı bir etkisinin olduğunu, yine bu yöntemin öğrencilerin öğrenme düzeylerinde de artışı sağladığını göstermiştir. Aykaç (2007) 5. sınıf sanat etkinlikleri dersinde "Müze Kültürü” öğrenme alanına bağlı "Tarihte Yaşam Kültürü” temasının öğretiminde öğrenci memnuniyetini yaratıcı drama yöntemini kullanılarak değerlendirmiştir. Uygulama sonucunda yaratıcı dramayla müzeye dönüştürülen sınıf ortamının ve müzelerin öğrenci motivasyonunu artırdığı, öğrenmenin kalıcılığını sağladığı ve öğrencinin mutluluğu üzerinde önemli bir etki yarattığını gözlemlemiştir. Uyan (2006) ise resim derslerini geleneksel yöntem ve drama yöntemi kullanarak işlediği tezinde, yaratıcı dramanın öğrencilerin derslerindeki başarılarını artırdığını gözlemlemiştir. Aynı şekilde Topçu da (2008) tezinde, görsel sanatlar dersinde 8 yaş grubu öğrencileriyle bir yaratıcı drama uygulaması yaparak süreç sonunda çıkan resimleri değerlendirmiştir. Bulgular, öğrencilerin yaratıcı dramayla işlenen ders boyunca eğlendiklerini, eğlenceli bir ders ortamı oluşturduklarını ve resim yaparken daha çok zevk aldıklarını göstermiştir. Ayrıca bu çalışmayla öğrencilerin gözlem ve düş güçlerini kullanarak ortaya çıkardıkları ürünlerde kendilerini rahatlıkla ifade ettikleri bulgular arasında yer almaktadır. Başka bir araştırmada da Kaya (2006), ilköğretim 3. sınıf öğrencileriyle görsel sanatlar dersinde drama yöntemiyle işlenen dersin öğrencilerin ilgilerini artırdı̆̆ını, onları çalışmaya daha istekli kıldığını ve öğrencilere çalışma disiplini kazandırdığını göstermiştir.

Yapılan araştırmalar öğrencilerin sanat eserlerini anlama ve kavramada geleneksel yöntemlerle öğrenmenin yeterli olmadığını, öğrencilerin yaparak ve yaşayarak öğrendiği yöntemlere ihtiyaçlarının daha çok olduğunu ortaya çıkarmıştır. Catterall ve Nugent (Akt. Bağatır, 2008), "Öğrenciler dünyalarında ve ilişkilerinde pasif ve evcil değil, aktif ve eleştirel olmalıdır". Öğrenmenin merkezinde olan öğrencinin aktif ve eleştirel olması için de öğretim yöntemlerinin bu aktifliği ve dinamikliği sağlayacak içeriğe sahip olması gerekir. Yaratıcı drama tam da burada karşımıza çıkmaktadır. Üstündağ’a $(2005,24)$ göre, “Öğretimde önemli olan, öğrenciyi edilgenlikten kurtararak bedenini ve duyu organlarını harekete geçirmektir. Yaratıcı dramayla öğrenciler konuların öğrenilmesine etkin olarak katılarak kendi yaptığıyla öğrenerek diğer yandan duyu organlarını da harekete geçirerek olay ya da durumları yaşamaktadır”.

Burçoğlu ve Aykaç (2013) çalışmalarında Neşet Günal'ın eserlerini yaratıcı drama yöntemiyle incelemiştir. Çalışmanın sonuçları öğrencilerde Neşet Günal'ın eserlerine karşı bakış açılarında olumlu değişimler göstermiştir. Öğrencilerin, eserlere daha iyi ve daha dikkatli bakma, eserlerden yola çıkarak neden sonuç ilişkisi kurma ve temel plastik değerlerle eserleri inceleme ve yorumlamayla gelen sonuçlar elde ettiğini belirtmişlerdir. Benzer bir çalışma Arıkız ve Beştepe (2016)'nin araştırmasında da teknoloji tasarım dersinin yaratıcı drama ile işlendiğinde dersin daha iyi anlaşıldığ yönündedir. Yapılan çalışmalar (Aykaç, 2007; Uyan, 2006; Topçu, 2008; Kaya, 2006; Burçoğlu ve Aykaç, 2013; Arıkız ve Beştepe, 2016 ) göstermektedir ki yaşanan gelişmelerle birlikte sanat eğitiminde olduğu gibi öğrencilerin sanat eserlerini kavramaları için geleneksel yöntemlerin yanında yaratıcı drama gibi pek çok disiplinlerarası yönteme de ihtiyaç duyulmaya başlanmıştır.

Yukarıdaki belirtilenler çerçevesinde drama yöntemi kullanılan bu çalışmada süreç boyunca öğrencilerin derse daha heyecanlı geldikleri ve sanat eserlerine karşı ilgilerinin arttı̆̆ gözlemlenmiştir. Çalışmaya başlarken yapılan ısınma hareketleri öğrencileri derse daha hızlı hazırlamış ve dikkatlerini daha fazla toplamalarını sağlamıştır. Doğaçlamalarda katılımcılar yaparak ve yaşayarak konuyu 
daha iyi kavramışlar, canlandırmada olay örgüsünü kurmaları ve bu olay örgüsünden yola çıkarak sonuca ulaşmaları daha hızlı olmuştur. Son olarak öğrencilerin ifadelerine baktı̆̆ımızda ise süreç boyunca yaşadıklarını, hissettikleri duyguları ve kendilerinde bıraktıkları izlenimleri ifade ettikleri görülmüştür. Araştırma boyunca katılımcıların çoğunluğu sanata bakış açılarının değiştiğini, sanat eserini çözümlemede eleştirel düşünme becerilerinin geliştirdiğini ifade etmişlerdir.

\section{Sonuç}

Drama yöntemiyle işlenen araştırma süreci, katılımcıların eleştirel anlamda daha fazla pratik yapmalarına olanak sağlamış ve öğrencilerin tutumlarında da olumlu değişimlerin olduğu görülmüştür. Katılımcıların sınıfta ve sınıf dışında eleştirel tutumlar sergiledikleri gözlemlenmiş ve özellikle bazı öğrencilerin etkinlikler sonunda evlerine döndüklerinde duvarlarda asılan resimleri yorumladıkları ve bu resimler hakkında aileleriyle konuştukları dile getirilmiştir. Bu bağlamda Leonardo Da Vinci'nin Son Akşam Yemeği adlı eserinin yaratıcı drama yöntemiyle çözümlenmesi ve alımlanmasında katılımcıların estetik deneyimlerinde, eseri çözümleme ve alımlama süreçlerinde gelişmenin olduğu gözlemlenmiştir. Bir resme nasıl bakılacă̆1, Son Akşam Yemeği resminin biçim içerik özelliklerinin, Son Akşam Yemeği resmi üzerinden sanatsal düzenleme ögelerinin öğrenciler tarafından öğrenildiği belirlenmiş̧ir. Araştırmanın tüm bulgularına bakıldığında, bir sanat eserinin yaratıcı drama yöntemiyle işlenmesi sonrasında yöntemin öğrencilere sanat eserleri ile ilgili farklı bakış açıları kazandırılabileceği ve öğrencilerde sanata karşı farkındalık oluşturulabileceği görülmüştür.

Araştırmada ulaşılan sonuçlardan hareketle; tüm öğretim kademelerinde, sanat eğitimi ile ilgili derslerde ve sanat eseri çözümleme ya da sanat eleştirisi uygulamalarında yaratıcı drama yönteminden yararlanılması önerilmektedir. 


\section{Kaynakça}

Arıkız, S. ve Beştepe, N. E. (2016). Tasarım sürecinde yaratıcılık "Teknoloji ve tasarım dersinin yaratıı drama yöntemiyle işlenmesi. Yaratıcı Drama Dergisi, 11(2), 47-64.

Aykaç, M. (2007). İlköğretim sanat etkinlikleri dersinde yaratıcı drama yönteminin öğrenci memnuniyeti açısından değerlendirilmesi. Yaratıcı Drama Dergisi, 1(3/4), 27-44.

Aykut, A. (2011). Sanat eğitiminde estetik. İstanbul: Hayalperet Yayınevi.

Bağatır D., R. (2008). Drama öğretim yönteminin resim- iş bölümü öğrencilerinin mesleki tutum ve başarılar1na etkisi. Yayımlanmamış doktora tezi, Dokuz Eylül Üniversitesi Eğitim Bilimleri Enstitüsü, İzmir.

Beştepe, N. E. (2006). Sanat eleştirisinde ölçüt sorunu. Mustafa Kemal Üniversitesi Sosyal Bilimler Enstitüsü Dergisi, 3(6). 1-9.

Botton, A. (2007). Mutluluğun mimarisi. İstanbul: Sel Yayınc1lık.

Burçoğlu, E. B. ve Aykaç, M. (2013). Sanat eserlerinin yaratıcı drama yöntemiyle incelenmesi. Mersin Üniversitesi Eğitim Fakültesi Dergisi, 9 (2), 181-191.

İlhan, A.Ç. (2007). Yaratıcı drama ile örtüşen çağdaş sanat akımları. Yaratıcı Drama Dergisi, 1(3-4), 139-154.

İlter, İ. (2014). Öğretim elemanlarının kullandığı yöntem ve tekniklere ilişkin öğretmen adaylarının görüşleri. Journal of International Social Research, 7(35). 562-575.

Kaya, Ö. (2006). İlköğretim 3. sınıf görsel sanatlar dersinde drama destekli eğitimin yaratıcı sürece katkıları. Yayımlanmamış yüksek lisans tezi, Gazi Üniversitesi Eğitim Bilimleri Enstitüsü, Ankara.

Özer, B. (2000). Kültür sanat mimarlık. İstanbul: Yem Yayın.

Read, H. ve Asgari, N. (2014). Sanatın anlamı. İstanbul: Hayalperest Yayınları.

Sağlam, T. (2006). Gavin Bolton: Drama, sanat, öğrenme. Yaratıcı Drama Dergisi. 1(2), 57-64.

San, İ. (1979). Sanatsal yaratma ve çocukta yaratıcılık. Ankara: Türkiye İş Bankası.

Tanilli, S. (1999). Yaratıcı aklın sentezi: Felsefeye giriş. Ankara: Adam Yayınları.

Topçu, A. K., (2008). Görsel sanatlar eğitiminde bir öğretim yöntemi olarak yaratıcı drama . Yayımlanmamış yüksek lisans tezi. Selçuk Üniversitesi Sosyal Bilimler Enstitüsü, Konya.

Uyan, Z. (2006). Resim öğretiminde (sanat eğitiminde) oyunun öğretime katkısı. Yayımlanmamış doktora tezi, Dokuz Eylül Üniversitesi Eğitim Bilimleri Enstitüsü, İzmir.

Üstündağ, T. (2002). Yaratıcı dramanın üç boyutu. Ö. Adıgüzel (Yay. Haz..) Yaratıcı Drama 1985-1998 Yazılar içinde (s. 333-341). Ankara: Natürel Yayıncılık.

Üstündağ T. (2005). Yaratıcllı̆a yolculuk. Ankara: Pegem Yayıncılık.

Vural, R. A. ve Somers, J.W. (2011). İlköğretimde drama kuram ve uygulama. Ankara: Pegem Yayınları.

Yıldırım, A. ve Şimşek, H. (2006). Sosyal bilimlerde nitel araştırma yöntemleri. Ankara: Seçkin Yayınları.

Yolcu, E. (2009). Sanat eğitimi kuramları ve yöntemleri. Ankara: Nobel Yayınları. 


\section{Ek1: Örnek Ders Planı (Üçüncü Oturum)}

Tarih : 06.06.2013

Yer : MEB'e Bağlı Bir Devlet Ortaokulu

Süre $\quad: 180 \mathrm{dk}$.

Konu : Bir Sanat Eserindeki Sanatsal Düzenleme Öğeleri (Leonardo da Vinci’nin Son Akşam Yemeği resminden hareketle)

Grup $\quad: 14 \mathrm{~K}$ ız, 2 Erkek $(10-11$ yaş arası toplam 16 katılımcı)

Yöntem : Yaratıcı Drama

Teknik : : Rol Oynama, Doğaçlama, Donuk İmge

Araç- Gereçler: Müzik (Shantel - Ex Oriente), Yaka Kartı, Sanatsal Düzenleme Öğelerini Gösteren Dijital Baskılar, 35x50 Resim Kağıdı, Yapıştırıcı, Pet Şişe Kapağ1, Kağıt, Gazete, Dergi,Taş İp, Pipet

\section{Kazanımlar:}

Sanatsal düzenleme öğelerini (çizgi, şekil, 1şık- gölge, doku, renk, biçim, değer, ton, mekan) kavrar.

Bir sanat eserinin oluşmasında sanatsal düzenleme öğelerinin önemini fark eder.

\section{Süreç}

\section{Hazırlık-Isınma}

\section{Etkinlik}

Lider, önceden hazırlanmış renkli yaka kartlarına yazılmış olan tasarım ve sanatsal düzenleme öğelerinin isimlerini katılımcılara dağıtarak bunları yakalarına takmalarını söyler. Katılımcılara bu yaka kartlarında yazılmış olan kelimelerin kendi isimleri olduğu söylenir. Daha sonra Lider o isimlerden birini ebe olarak seçer. Ebe müzik eşliğinde katılımcılardan birini ebelemek için koşar. Ebeleneceğini anlayan kişi başka birinin ismini (sanatsal düzenleme öğeleri) söylerse ebe o kişi olur ve ebe o yöne doğru koşar. Etkinlik belli bir süre devam ettirilir.

\section{Etkinlik}

Lider, tasarım ve sanatsal düzenleme öğelerinin isimlerinin yazılı olduğu yaka kartlarını katılımcılara tekrar dağıtır. Liderin kendisi de bir yaka kartı takarak ben bir resme baktım içinde (yaka kartında yazılı olan öğe) doku vardı ama renk yoktu diyerek etkinliği başlatır. Renk öğesinin yazılı olduğu katılımcı da bir başka katılımcının yakasında yazılı olan öğeyi aynı cümle içerisinde kullanarak etkinliği devam ettirir.

\section{Etkinlik}

Lider sınıfın duvarlarına çizgi, şekil, ışık- gölge, doku, renk, biçim, değer, ton, mekan gibi sanatsal düzenleme öğelerini gösteren resimleri asar. Katılımcılardan bu resimlerin altına resimlerin ne olduklarıyla ilgili birer kelime yazmaları istenir. Burada katılımcılardan resmin altında daha önce ne yazıldığından çok kendileri için ne ifade ettiğinin önemli olduğu vurgulanır. Etkinlik bitiminde resimler gezilerek yazılan ortak kelimeler lider tarafından kalemle daire içine alınır. 


\section{Etkinlik}

Lider önceden hazırlamış olduğu tasarım öğelerinin yazılı olduğu bilgi kartları kapalı bir biçimde atölyenin zeminine dağınık bir şekilde bırakılır.

Bilgi kartlarındaki tasarım ilke ve öğelerini açıklayan yazılarının anlaşılabilir, kısa ve öz olmasına dikkat edilmiştir. Tüm katılımcılara, bir müzik açılacağı ve müzikle beraber yerde kapalı duran kâğıtların etrafinda dolaşmaları ve müzik durduğunda, o an bulundukları yere yakın olan kâğıdı alıp okumaları söylenir.

Müzik tekrar başladığında aldıkları kâğıdı aynı yere kapalı bir şekilde bırakıp müzik eşliğinde tekrar dolaşmaları istenir.

Katılımcıların yerdeki kâğıtların tümünü okuması sağlandıktan sonra etkinlik sonlandırılır.

\section{Etkinlik}

Lider katılımcılar çemberdeyken daha önceden hazırlayıp kapalı bir torbaya karışık bir şekilde koyduğu tasarım ilkelerini anlatan özlü sözleri katılımcıların tek tek torbadan çekmeleri sağlanır. Katılımcılardan mekanın ortasına gelerek torbadan çekilen kağıtta yazılanı gür ve anlaşı1ır bir sesle okuyup donuk imgeyle göstermeleri istenir. Tüm katılımcılar okuyana kadar etkinlik devam ettirilir.

Torba içerisinde bulunan Tasarım ilke ve öğelerinden yola çıkarak yazılan yazılar;

1. Ben bir Çizgiyim; Bir ip gibiyim. Bükülüp her şekle girebilirim.

2. Ben Işık- Gölgeyim; Ben olmadan hiçbir şey göremezsiniz.

3. Ben bir Şekilim; Beni görebilir ve neye benzediğimi söyleyebilirsiniz.

4. Ben bir Dokuyum; Bana bakarak ve dokunarak hissedebilirsiniz.

5. Ben bir Rengim; Her yerde beni görebilirsiniz.

6. Ben bir Biçimim; Bana dokunabilir ve etrafımda dönebilirsiniz.

7. Ben bir Ton'um; Hem açılıp, hem kapanabilirim.

8. Ben bir Mekanım; Her yerde ben varım. Çünkü siz her zaman bir mekanın içindesiniz.

\section{Canlandirma}

\section{Etkinlik}

Lider katılımcıları 3 gruba ayırır. Lider katılımcılara karşınızda hayali bir tablo var. Fakat bu tablo henüz oluşmamış. Her katılımcıdan bu hayali tabloyu tasarım öğelerinden birini seçerek oluşturmanız isteniyor. Bu durumda sizler konuşan canlı birer tasarım öğesisiniz. Tablonun içerisine girip orada kendinize bir yer bulmanız ve sizden sonra gelecek öğelere izin vermemeniz isteniyor. Eğer gelirlerse neden buraya geldiklerini sormanızı ve onlara gerek duyulmadığını söylemeniz isteniyor. İzin verecekseniz onlardan mantıklı bir sebep bulmalarını isteyeceksiniz. Sonradan tabloya giren katılımcılara da ben (biz) olmadan tablonun eksik kalacağı, çünkü..........ile başlayan bir cümleyi tamamlamaları istenir. Lider el çırpar ve bir öğe tabloya dahil olur. Her katılımcıya tasarım öğelerinin o ana kadar hangisi söylenmemişse onunla dahil olunacağı hatırlatılır. 
Her giden bir öncekinin sorularına maruz kalıp neden burada olduklarını ve ben ya da biz olmadan tablonun eksik kalacağını savunmaları istenir.

Tüm katılımcılar tabloya dahil olana kadar etkinlik devam ettirilir.

\section{Etkinlik}

Röprodiksiyon: Orijinal bir resmin bakarak yeniden yapılması " kopya edilmesi şeklinde katılımcılara söylenir. Katılımcılardan ikişer kişilik gruplar oluşturmaları istenir. İkililerden biri A diğeri B olur. Lider her gruptan B olanlara sanatsal düzenleme öğelerinden birini verir ve yönergesini ekler:

' 'A' lar sizler ünlü bir ressamsınız. Günlerce çalıştığınız çalışma Leonardo'nun “Son Akşam Yemeği” adlı tablosunun röprodüksiyonu (yeniden yapma). Tabloyu günlerce uğraşıdan sonra bitirdiniz. Bitirdiğiniz gün galeri sahibi arkadaşınızı çağırıyorsunuz. Çünkü paraya ihtiyacınız var ve tabloyu satmak için ikna etmelisiniz."

"B” ler sizler galeri sahibisiniz. Ressam arkadaşınız sizi bitirdiği resmi görmeniz için davet ediyor. Çok merak ediyorsunuz. Ve gittiğinizde resmi özellikle size verilen tasarım öğesinin eksik olduğunu kontrol ediyorsunuz. Buna göre bir karar vermeniz gerekiyor.

Doğaçlamalar A'ların hoşgeldin demesiyle başlar.

\section{Değerlendirme}

\section{Etkinlik}

Lider öğrencilere 35x50 resim kağıdı, yapıştırıcı ve pet şişe kapağı, kağıt gazete, dergi, taş, ip, pipet, bu ve benzeri artık malzemeleri ve her bir gruba yeterli miktarda dağıtır. Daha sonra katılımcılardan dağıtılan bu artık malzemeleri de kullanarak tasarım öğelerini göz önünde bulundurup bir kolaj(kes-kopar düzenle ve yapıştır) çalışması yapmaları istenir. Yapılan tüm çalışmalar gezilerek üzerinde konuşulur. 
